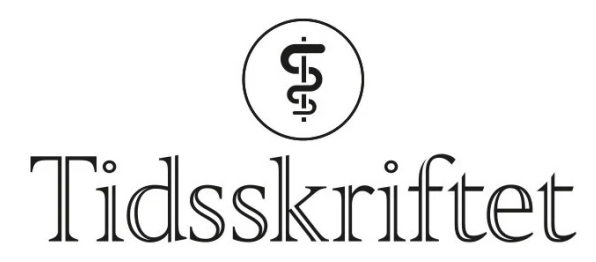

DEN NORSKE LEGEFORENING

\title{
Larynksmaske ved nyfødtresuscitering til liten nytte
}

FRA ANDRE TIDSSKRIFTER

TORBJØRN ØYGARD SKODVIN

Tidsskriftet

Bruk av larynksmaske under resuscitering av nyfødte i Uganda hadde ingen effekt på dødelighet eller forekomst av hjerneskade.

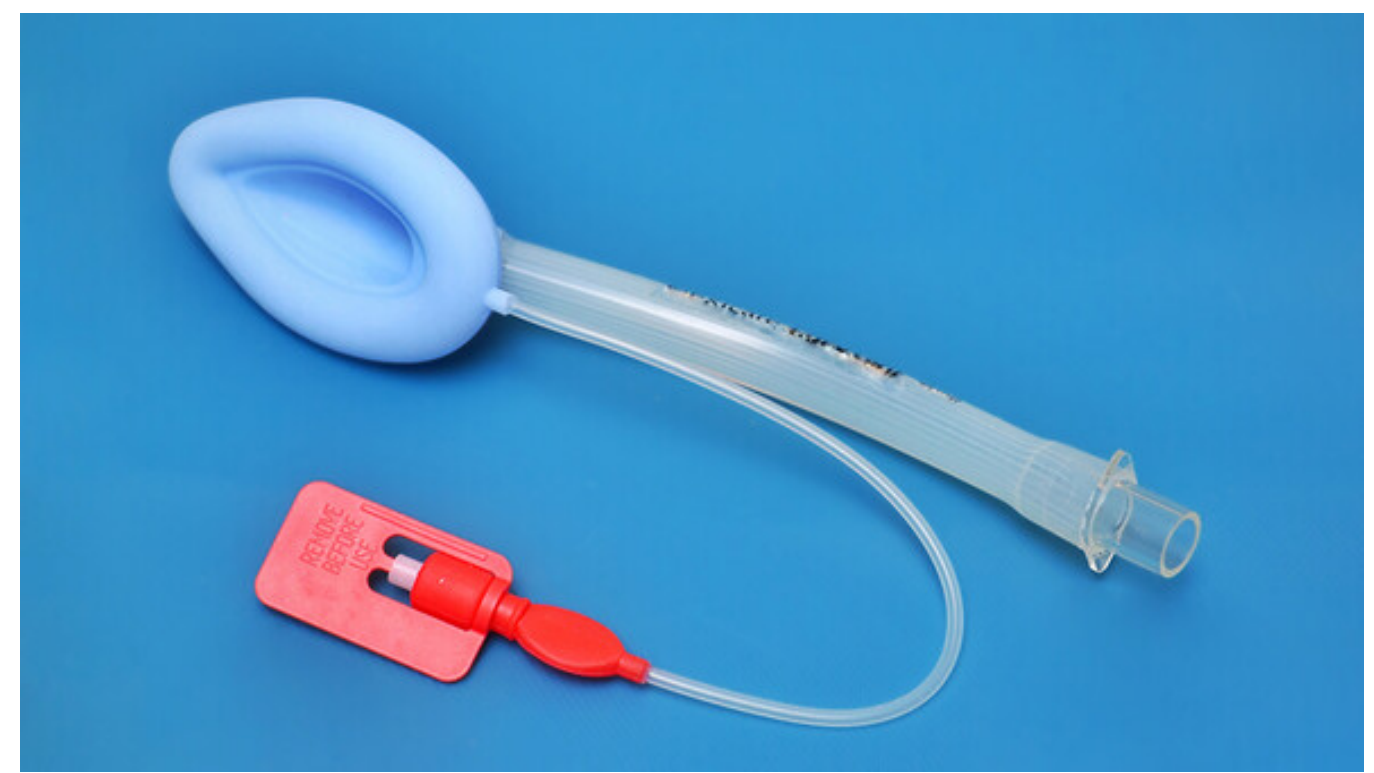

Illustrasjonsfoto: j-the photoholic / iStock

Asfyksi er den tredje hyppigste årsaken til neonatal død. Effektiv ventilasjon er den viktigste behandlingen. Maskeventilasjon av nyfødte er en vanskelig ferdighet å lære. Ved ufullstendig maskeventilasjon er endotrakeal intubasjon gjerne neste steg, men slik behandling er sjeldent tilgjengelig i lavinntektsland.

På et stort tertiærsykehus i Kampala, Uganda, ble 1160 nyfødte med behov for ventilasjonsstøtte randomisert til enten maskeventilasjon eller larynksmaske. Larynksmasken ble lagt av jordmødre. Studien var et samarbeid mellom forskere fra Uganda, Norge, Sverige og Italia, og er nylig publisert i New England Journal of Medicine (1). 
I løpet av syv dager døde $22 \%$ av de nyfødte som ble ventilert med larynksmaske, mot $18,4 \%$ av dem som ble ventilert med maske (relativ risiko 1,27; $95 \% \mathrm{KI}$ o,84 til 1,93). Henholdsvis $11 \%$ og $10 \%$ av de nyfødte i hver gruppe ble innlagt på intensivavdeling med hypoksiskiskemisk hjerneskade (relativ risiko 1,21; $95 \% \mathrm{KI}$ o,9o til 1,63). Det var heller ingen forskjeller i bivirkninger som oppkast og larynksspasme.

- Den gode nyheten fra denne studien er at larynksmaske er trygt å bruke også for helsepersonell som ikke er leger, sier Thorkild Tylleskär, som er barnelege og professor ved Senter for internasjonal helse ved Universitetet i Bergen og studiens sisteforfatter.

- Den dårlige nyheten er at svært mange nyfødte barn på store tertiærsykehus i lavinntektsland allerede har fått så store hjerneskader at de ikke kan reddes gjennom tidlig og effektiv maskeventilasjon. For å redde flere kreves bedre fosterovervåkning under fødselen og tidligere tiltak ved dårlig fosterlyd, sier Tylleskär.

\section{LITTERATUR}

1. Pejovic NJ, Myrnerts Höök S, Byamugisha J et al. A randomized trial of laryngeal mask airway in neonatal resuscitation. N Engl J Med 2020;383: 2138-47. [PubMed][CrossRef]

Publisert: 7. mai 2021. Tidsskr Nor Legeforen. DOI: 10.4045/tidsskr.21.0223

(C) Tidsskrift for Den norske legeforening 2023. Lastet ned fra tidsskriftet.no 26. april 2023. 